\title{
PENINGKATAN KETERAMPILAN SANTRIPRENEUR MELALUI PELATIHAN OLAH LIMBAH KAYU MENJADI PRODUK YANG BERNILAI EKONOMIS
}

\author{
Fachrurrozie, Agus Wahyudin, Widiyanto, Ahmad Nurkhin, Muhammad Feriady \\ Fakultas Ekonomi, Universitas Negeri Semarang \\ E-mail : fachrurais@mail.unnes.ac.id
}

\begin{abstract}
ABSTRAK
Keterampilan wirausaha santri adalah sangat penting untuk diasah dan ditingkatkan. Santripreneur adalah jawaban kalangan pondok pesantren untuk menjawab tantangan zaman industri 4.0. Pondok pesantren As Salafy Al Asror adalah pesantren yang memberikan perhatian lebih dalam pengembangan kewirausahaan santri. Santri diharapkan menjadi warga yang mandiri dan mampu menghasilkan produk-produk dari bahan apa pun, termasuk dari limbah kayu yang tersedia cukup melimpah. Melalui kegiatan pengabdian ini, tim dari FE UNNES akan memberikan tambahan keterampilan kepada santri prenenur. Kegiatan pengabdian telah dilaksanakan bersama mitra pengabdian (Pondok Pesantren As Salafy Al Asror) dan Direktorat Jenderal Industri Kecil, Menengah dan Aneka Kementerian Perindustrian yang mempunyai program sejenis untuk meningkatkan keterampilan wirausaha santri melalui dan pelatihan dan pendampingan olah limbah kayu. Kegiatan pertama telah dilaksanakan pada tanggal 30 Maret sampai dengan 2 April 2021 dengan narasumber utama dari Kementerian Perindustrian. Selama 4 hari, santri mendapatkan pelatihan bagaimana menghasilkan produk ekonomis dari bahan limbah kayu. Kementerian juga memberikan alat agar santri dapat menghasilkan produk terbaik dan berkelanjutan. Tim kementerian melakukan monev untuk mengetahui pemanfaatan oleh santri yang telah sesuai dengan yang diharapkan. Tim pengabdi memberikan pendampingan bagi tim Kementerian saat pelatihan dan monev yang telah dilakukan. Tim pengabdi juga telah menyelenggarakan kegiatan lanjutan pada tanggal 16 Oktober 2021 untuk menguatkan semangat dan motivasi santri dalam menghasilkan produk inovatif bernilai ekonomis dari bahan limbah kayu. Tim pengabdi berusaha untuk memberikan pendampingan teknis kepada santri untuk terus berkreasi dalam menghasilkan produk. Tim pengabdi bersama pengasuh pondok pesantren juga memberikan pemahaman kepada santri untuk mampu memasarkan produk yang telah dihasilkan. Pengalaman yang dimiliki dibagi kepada santri yang sangat antusias mengikuti kegiatan untuk tetap menjaga kualitas produk yang telah dihasilkan.
\end{abstract}

Kata Kunci: keterampilan bisnis, olah limbah kayu, santri-preneur, pondok pesantren

\section{PENDAHULUAN}

Keterampilan wirausaha santri adalah sangat penting untuk diasah dan ditingkatkan. Santripreneur adalah jawaban kalangan pondok pesantren untuk menjawab tantangan zaman industri 4.0. Santri akan diberikan bekal untuk berpikir kreatif dan mampu memanfaatkan peluang yang ada. Paling tidak untuk mencukupi kebutuhan dan menghasilkan aktivitas bisnis bersama warga sekitar. Banyak kegiatan yang 
dapat dilakukan untuk meningkatkan keterampilan wirausaha santri dalam rangka mencetak santripreneur. Menangkap peluang yang ada di sekitar pondok pesantren adalah salah satu cara untuk memberikan stimulus bagi santri untuk berlatih berpikir kreatif.

Pondok Pesantren As Salafy Al Asror adalah pondok yang didirikan oleh Alm. Kiai Zubaidi pada tahun 1980 dan menyelengarakan pendidikan Islam di wilayah Kelurahan Patemon Gunungpati Kota Semarang (Suratno, 2006). Bersama masyarakat sekitar, Kiai Zubaidi berusaha untuk memenuhi kebutuhan sarana prasarana pondok sehingga aktivitas pondok bisa berjalan dengan lebih baik. Saat ini pondok pesantren telah dilanjutkan pengelolaannya ke $\mathrm{KH}$ Al Mamnuhin Kholid, putra kelima dari Kiai Zubaidi. Perkembangan pondok sangat pesat dengan bertambahnya santri dan sekolah formal yang diselenggarakan seperti SMK dan MITQ.

Pengembangan jiwa wirausaha santri adalah sangat penting dan masih perlu dilakukan. Pondok telah mempunyai unit usaha untuk pengembangan jiwa wirausaha sekaligus membantuk biaya operasional pondok (Kardoyo et al., 2018). Pondok bersama mitra telah memberikan bekal pemahaman kepada santri mengenai financial technology (Fachrurrozie et al., 2021). Pondok juga terlibat dalam pengembangan BLK (Balai Latihan Kerja) untuk mendorong minat wirausaha santri. $\mathrm{KH}$ Al Mamnuhin Kholid sebagai pengasuh juga berharap santri mampu lebih mandiri dan dapat memanfaatkan peluang yang ada. Kesempatan telah diberikan kepada santri seperti mengajak santri untuk berlatih berjualan atau sejenisnya.

Kegiatan pengabdian ini merupakan salah satu cara yang ditempuh pondok untuk meningkatkan keterampilan berwirausaha santri. Pondok Pesantren As Salafy adalah mitra kerja sama UNNES (termasuk FE) khususnya di bidang pengabdian kepada masyarakat. Dengan kerja sama ini diharapkan juga dapat memberikan bekal konkret dan mengena untuk menarik perhatian santri untuk terus berkreasi dan berinovasi.

Keberadaan limbah kayu dari kerja sama pondok pesantren dengan perusahaan Kubota Semarang menghadirkan peluang untuk bisa mengolah limbah kayu tersebut menjadi produk yang lebih bernilai ekonomis. Selama ini, limbah kayu hanya 
digunakan sebagai bahan bakar di dapur pondok. Oleh karena itu, diperlukan sentuhan tim ahli untuk memanfaatkan limbah kayu. Tim pengabdian kepada masyarakat FE UNNES juga mempunyai kompetensi tersebut, untuk mendorong ide kreatif dan inovatif dalam mengolah limbah kayu yang ada. Mitra kerja sama FE UNNES juga dapat dilibatkan dalam kegiatan pengabdian ini.

Inovasi pengelolaan limbah kayu sangat beragam. Kerajinan Limbah Kayu Haryono Wood Craft yang terletak di sentra industri mebel dan kerajinan di Serenan Klaten memanfaatkan batang dan ranting pohon berdiameter relatif kecil yang biasanya hanya dipergunakan sebagai kayu bakar. Produk yang dihasilkan berupa mebel-mebel dan kerajinan unik yang sangat diminati pasar (Utomo et al., 2018). Bahkan, limbah gergaji kayu jadi dapat dimanfaatkan sebagai sumber energi alternatif dengan metode pirolisis (Mutmainnah, 2017). Pelet serbuk gergajian menambah potensi dari limbah kayu yang dapat diubah menjadi sumber energi listrik alternatif (Sundari, 2017). Smart wall light juga bisa dibuat dari memanfaatkan material limbah kayu (PN Arya et al., 2020).
Pemanfaatan limbah kayu dapat memiliki tujuan strategis dan bersifat social constructive, dan orientasi penggunaan bahan yang tidak terpakai menjadi bernilai ekonomis. Di samping itu akan hemat dalam pembiayaan, secara aplikatif dalam desain kursi akan membuka cakrawala pandang inovatif pengrajin (Badriyah, 2013). Upcycling merupakan salah satu metode pengolahan material dengan memanfaatkan limbah atau sampah menjadi material baru yang dapat dijadikan produk terbarukan (PN Arya et al., 2020).

Produk inovatif dari limbah kayu agar bernilai ekonomis tentunya tidak mudah dilakukan. Kemampuan membuat desain yang memenuhi kebutuhan konsumen, adalah sangat penting untuk dilakukan (Utomo et al., 2018). Dengan demikian, produk akan memiliki kualitas yang baik. Di samping itu, memiliki media promosi yang menarik dan menjangkau konsumen yang lebih luas, akan mampu memperluas pasar bahkan ekspor ke luar negeri.

Berdasarkan uraian di atas, maka kegiatan rumusan masalah dalam kegiatan pengabdian ini adalah bagaimana meningkatkan keterampilan 
santri melalui olah limbah kayu menjadi produk bernilai ekonomis? Tujuan dari kegiatan pengabdian ini adalah untuk meningkatkan pemahaman dan keterampilan santri melalui pelatihan olah limbah kayu menjadi produk yang bernilai ekonomis.

\section{METODE PELAKSANAAN}

Kegiatan pengabdian dilaksanakan dalam bentuk pelatihan, artinya peserta kegiatan akan praktik langsung membuat produk bernilai ekonomis dari bahan limbah kayu. Narasumber memberikan gambaran mengenai produk yang dapat dihasilkan dari limbah kayu kemudian narasumber memberikan contoh pembuatannya. Tim pengabdian menyiapkan bahan dan alat yang dibutuhkan dibantu oleh mitra pengabdian. Setelah pelatihan dan pendampingan, tim pengabdian melakukan monitoring dan evaluasi terhadap peserta kegiatan yang tetap aktif menghasilkan produk hasil olah limbah kayu. Tim pengabdian memberikan reward bagi peserta aktif dan terampil serta kreatif.

Tahapan pelaksanaan kegiatan pengabdian adalah sebagai berikut:
1. Tahapan Persiapan

Persiapan yang dilaksanakan adalah bersilaturahmi dengan pengasuh pondok pesantren, yaitu $\mathrm{KH} \mathrm{Al}$ Mamnukhin Kholid dan narasumber yang bekerja sama dalam penyelenggaraan pengabdian. Pondok pesantren yang menjadi mitra utama dalam kegiatan pengabdian adalah Ponpes Assalafy Al Asror Patemon. Tim pengabdi telah menjalin hubungan yang baik selama ini. Ponpes Assalafy Al Asror telah menjadi mitra pengabdian selama tiga tahun terakhir. Narasumber yang menjadi mitra pengabdian adalah tim dari Direktorat Jenderal Industri Kecil, Menengah dan Aneka Kementerian Perindustrian yang mempunyai keterampilan mengolah produk dari bahan limbah kayu. Tim pengabdian bersama mitra kemudian menentukan waktu dan tempat pelaksanaan serta sasaran target kegiatan pengabdian. Sehingga kegiatan pengabdian dapat terlaksana dengan baik. Tim pengabdian menyiapkan materi, bahan, dan konsumsi kegiatan bersama mitra pengabdian. 
2. Tahapan Pelaksanaan

Tim pengabdian menjadi narasumber bersama tim dari Direktorat Jenderal Industri Kecil, Menengah dan Aneka Kementerian Perindustrian dalam paparan materi pengolahan limbah kayu menjadi produk bernilai ekonomis. Mitra narasumber memberikan contoh pembuatan produk dari limbah kayu bersama tim pengabdian. Tim pengabdian juga memberikan pendampingan terhadap kreasi santri dalam menghasilkan produk dari limbah kayu. Di awal kegiatan pengabdian, tim pengabdi melakukan tes awal untuk mengetahui pemahaman santri dalam mengolah produk dari limbah kayu. Dan di akhir pengabdian, post-test diadakan untuk mengetahui pemahaman dan keterampilan peserta. Tim pengabdi menilai produk yang telah dihasilkan.

3. Tahapan Evaluasi

Kegiatan evaluasi dimanfaatkan untuk mengetahui sejauh mana keberhasilan pelaksanaan kegiatan pengabdian, baik dalam tataran pelaksanaan maupun peningkatan pemahaman dan keterampilan sasaran pengabdian (santri-preneur).
Kegiatan evaluasi dilaksanakan secara bersamaan dengan tahapan kegiatan pengabdian lainnya. Indikator keberhasilan pelaksanaan kegiatan pengabdian ini adalah; (1) telah berhasil melaksanakan seluruh tahapan kegiatan pengabdian; (2) kegiatan pengabdian dipublikasikan pada artikel di Media Cetak Media Nasional; (3) Publikasi di Jurnal nasional S3/S4/S5/S6, jurnal nasional ber-ISSN (Non Sinta); dan (4) menghasilkan produk olah limbah kayu yang bernilai ekonomis.

\section{HASIL DAN PEMBAHASAN}

\section{Pelaksanaan Kegiatan Pengabdian}

Kegiatan pengabdian masyarakat ini telah dilaksanakan pada hari Sabtu, 16 Oktober 2021 di ruang tamu Pondok Pesantren As Salafy Al Asror. Kegiatan ini dilaksanakan bersama Direktorat Jenderal Industri Kecil, Menengah dan Aneka Kementerian Perindustrian yang mempunyai program Pendampingan Teknis Produksi WUB IKM Kerajinan Limbah Kayu berbasis Pondok Pesantren. Ide yang sama dengan tim pengabdian dalam rangka program penumbuhan wirausaha baru di Pondok Pesantren As Salafy Al Asror 
Gunungpati Semarang. Kegiatan ini melibatkan 20 santri yang mempunyai komitmen untuk meningkatkan keterampilan dalam olah kayu untuk menghasilkan produk yang bernilai ekonomis.

Kegiatan pengabdian ini merupakan lanjutan dari kegiatan yang telah dilaksanakan oleh Direktorat Jenderal Industri Kecil, Menengah dan Aneka Kementerian Perindustrian pada tanggal 30 Maret sampai dengan 2 April 2021. Kegiatan dibuka oleh Kepala Dinas Perindustrian dan Perdagangan Provinsi Jawa Tengah, Bp. Arif Sambodo, SE, M.Si. Dalam sambutan pada acara pembukaan Program Penumbuhan Wirausaha Baru di Pondok Pesantren (30/03/2021), diharapkan dengan program ini, para santri khususnya santri Al Asror dapat bersemangat menjadi pelaku usaha yang dapat memperkuat perekonomian berbasis syariat serta mengurangi angka pengangguran. Peserta kegiatan mendapatkan pengenalan alat dan cara penggunaannya. Gambar 1 menunjukkan salah satu peserta sedang menyelesaikan produk yang menjadi gagasannya.

Pada kegiatan tahapan pertama ini, tim pengabdi menjadi pendamping dalam pelaksanaan pelatihan oleh tim Dirjen Industri Kecil, Menengah dan Aneka Kementerian Perindustrian. Bersama memberikan pelatihan secara intensif kepada peserta agar mampu berkreasi dan mempunyai keterampilan dalam membuat produk inovatif bernilai ekonomis dengan bahan dasar limbah kayu. Tim pengabdi juga bersama tim dari Kementerian Perindustrian dalam monitoring dan evaluasi pasca kegiatan pelatihan. Kegiatan monev telah dilaksanakan selama dua kali, di antaranya pada tanggal 19 September 2021. Diketahui bahwa peserta tetap berkelanjutan dalam memanfaatkan alat yang telah dihibahkan dengan tetap berkreasi membuat produk inovatif seperti gantungan kunci, asbak, vas bunga dan lainnya. Dari monev kedua ini juga diketahui bahwa diperlukan kegiatan lanjutan untuk menguatkan pengalaman yang telah diperoleh.

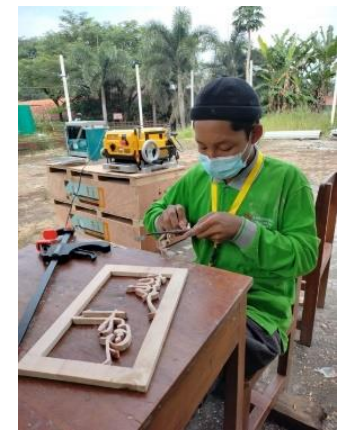

Gambar 1. Salah satu peserta kegiatan menyelesaikan produk kreatifnya 


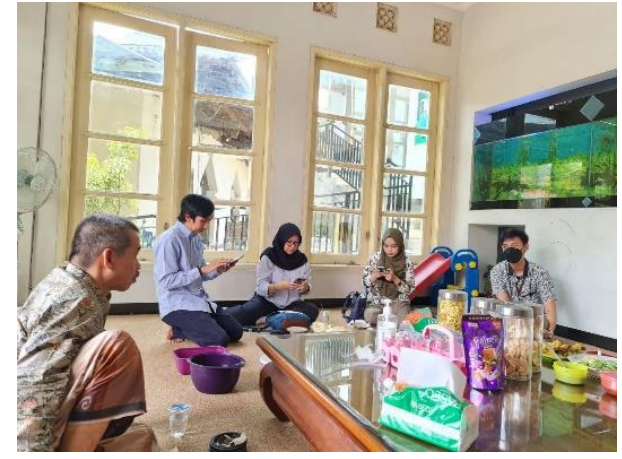

Gambar 2. Tim monev dari Dirjen Kementerian Perindustrian

Tim pengabdian melaksanakan kegiatan lanjutan, merespons hasil monev dari Kementerian Perindustrian. Tujuannya adalah untuk menjaga keberlangsungan semangat dan motivasi santri dalam menghasilkan produk bernilai ekonomis dari limbah kayu. Kegiatan ini dilaksanakan pada tanggal 16 Oktober 2021. Kegiatan dilaksanakan di ruang tamu Pengasuh Pondok Pesantren Al Asror. Kegiatan diikuti 7 santri yang telah terlibat dalam program pelatihan. Tim pengabdi memberikan materi tambahan untuk meningkatkan motivasi santri dan juga memberikan suntikan bahan yang dibutuhkan untuk menyelesaikan produk yang telah dihasilkan. Santri masih menghadapi keterbatasan dalam menghasilkan produk inovatif dan bagaimana cara memasarkannya. Oleh karena itu, tim pengabdi juga memberikan materi mengenai strategi pemasaran produk ekonomis dari limbah kayu. Santri berfokus pada kegiatan produksi dan tim pengabdi memberikan pendampingan pemasaran produk, baik secara daring maupun konvensional.

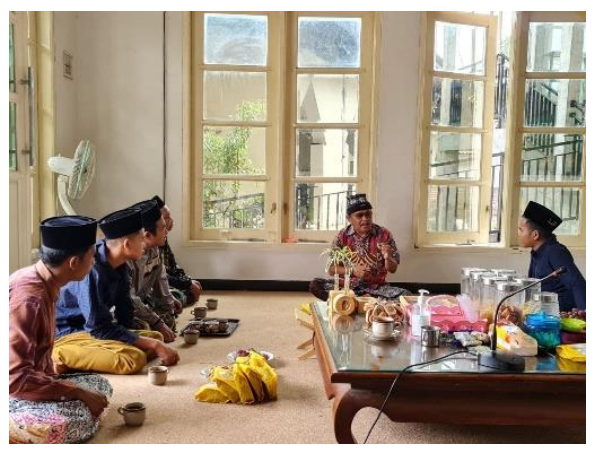

Gambar 3. Narasumber mengulas produk yang telah dihasilkan santri

Narasumber pada kegiatan lanjutan ini adalah anggota pengabdi yaitu Dr. Widiyanto, MBA., MM. yang telah mempunyai pengalaman dalam pengembangan kewirausahaan. Narasumber bertukar pengalaman dan juga memberikan penguatan kepada santri dalam menciptakan ide cerdas yang efisien dan bernilai ekonomis. Narasumber mengulas terlebih dahulu produk yang telah dihasilkan santri untuk mengetahui keunggulan dan kekurangannya. Produk yang telah dihasilkan diantaranya adalah vas bunga, asbak, meja lipat, jam kayu, bingkai foto, gantungan kunci dan lainnya. Narasumber bersemangat 
dalam memberikan komentar positif sekaligus memberikan masukan kepada peserta untuk meningkatkan kualitas produk yang telah dihasilkan. Narasumber juga memberikan contoh konkret untuk meningkatkan nilai lebih dari produk tersebut. Narasumber berharap bahan limbah yang digunakan adalah yang mudah ditemukan di sekitar pondok sehingga tidak perlu mengeluarkan biaya yang lebih banyak lagi. Dampaknya adalah pada harga jual produk nantinya.

Diskusi dan sharing menjadi lebih hidup karena peserta sangat antusias untuk mengembangkan produk ekonomis dari limbah kayu. Di sisi lain, pengasuh pondok, $\mathrm{KH}$. Al Mamnuhin Kholid atau yang biasa disapa Gus Nuhin juga memberikan ide dan penguatan atas gagasan kreatif santri. Gus Nuhin menceritakan pengalamannya dalam berwirausaha dan pengalamannya selama menjadi santri. Gus Nuhin sangat mendukung kegiatan ini dan usaha santri untuk kreatif dan berwirausaha. Pengasuh mendampingi kegiatan dengan baik. Peserta mampu menyebutkan ciri produk yang dicari oleh konsumen, yaitu murah, berkualitas, dan mudah ditemukan.

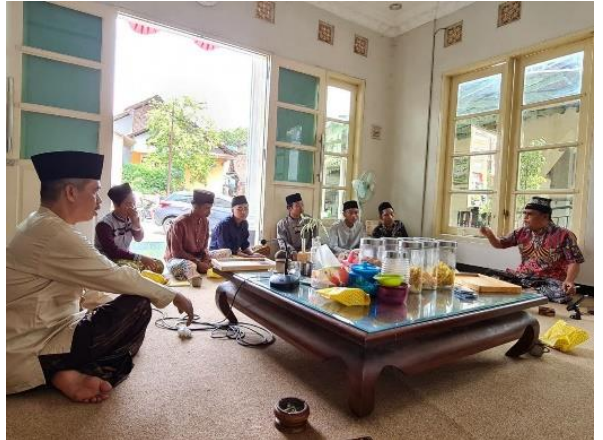

Gambar 4. Pengasuh berpartisipasi aktif dalam diskusi

Materi yang disampaikan oleh narasumber berikutnya adalah mengenai pemasaran. Kelemahan yang umum adalah santri bisa membuat produk tetapi lemah dalam memasarkannya. Narasumber memberikan pengalamannya dalam meningkatkan penjualan produk yang telah dibuat. Berbagai metode harus ditempuh agar produk tersebut dikenal dan laku di pasaran. Keunggulan pondok pesantren Al Asror harus menjadi keunggulan produk yang dihasilkan karena telah mempunyai nama di masyarakat dan keluarga santri. Kegiatan sambangan bisa menjadi tempat untuk memasarkan produk. Keluarga santri saat berkunjung ke pondok bisa menjadi objek jual produk. Di samping itu, produk yang dihasilkan bisa menjadi suvenir bagi santri atau siswa baru di lingkungan pondok pesantren. Terakhir, pemasaran online adalah jalur utama untuk 
meningkatkan penjualan harian. Perlu dikembangkan media online secara intensif untuk media pemasaran produk.

Narasumber juga memberikan order kepada santri untuk menyelesaikan satu produk. Order ini bertujuan sebagai pekerjaan rumah bagi peserta. Gus Nuhin juga memberikan order untuk membuat nampan atau tempat cangkir atau gelas yang dapat digunakan ketika menyajikan minuman kepada tamu yang bersilaturahmi ke pondok. Tim pengabdi memberikan reward berupa kaos kepada peserta kegiatan. Kegiatan diakhiri dengan foto bersama dan makan bersama.

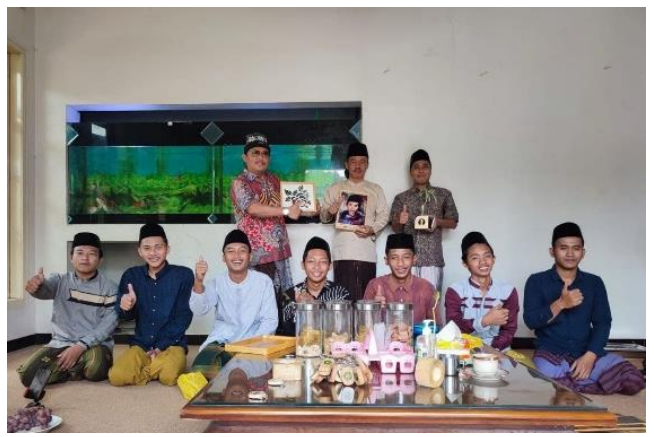

Gambar 5. Foto bersama pengasuh, narasumber, dan peserta kegiatan

\section{Evaluasi Pelaksanaan Kegiatan Pengabdian}

Kegiatan pengabdian ini telah berhasil dilaksanakan dengan baik, diukur dengan indikator keberhasilan pelaksanaan kegiatan pengabdian. Peserta telah mampu menghasilkan produk inovatif bernilai ekonomis dari bahan limbah kayu berupa gantungan kunci, papan, asbak, vas bunga, dan lainnya. Peserta juga sangat antusias mengikuti kegiatan dan mampu menyampaikan gagasan dan ide yang dimiliki. Peserta juga memberikan responsa tau jawaban dengan cepat Ketika tanya jawab. Tim pengabdi juga telah menghasilkan dua draft artikel yang akan dipublikasikan pada media lokal/nasional dan artikel pada jurnal nasional.

Keberhasilan pelaksanaan kegiatan pengabdian dikarenakan beberapa hal sebagai berikut;

1) Kegiatan pendampingan teknis yang telah dilaksanakan oleh Direktorat Jenderal Industri Kecil, Menengah dan Aneka Kementerian Perindustrian. Hal ini berdampak pada keterampilan santri menjadi lebih baik karena pemateri adalah praktisi dan ahli serta berpengalaman di bidang olah limbah kayu. Peralatan yang ada juga sangat mendukung kegiatan ini dan sangat memadai untuk terus berlanjut bagi santri.

2) Dukungan penuh dari pengasuh Pondok Pesantren As Salafy Al Asror. Gus Nuhin sangat mendung 
kegiatan pengabdian ini dengan terlibat langsung dan menyampaikan ide dan gagasannya.

3) Peserta kegiatan yang partisipatif dan mempunyai kesungguhan dalam mengikuti kegiatan.

\section{PENUTUP}

\section{Simpulan}

Kegiatan pengabdian telah dilaksanakan bersama mitra pengabdian (Pondok Pesantren As Salafy Al Asror) dan Direktorat Jenderal Industri Kecil, Menengah dan Aneka Kementerian Perindustrian yang mempunyai program sejenis untuk meningkatkan keterampilan wirausaha santri melalui dan pelatihan dan pendampingan olah limbah kayu. Kegiatan pertama telah dilaksanakan pada tanggal 30 Maret sampai dengan 2 April 2021 dengan narasumber utama dari Kementerian Perindustrian. Selama 4 hari, santri mendapatkan pelatihan bagaimana menghasilkan produk ekonomis dari bahan limbah kayu. Kementerian juga memberikan alat agar santri dapat menghasilkan produk terbaik dan berkelanjutan. Tim kementerian melakukan monev untuk mengetahui pemanfaatan oleh santri yang telah sesuai dengan yang diharapkan. Tim pengabdi memberikan pendampingan bagi tim Kementerian saat pelatihan dan monev yang telah dilakukan.

Tim pengabdi juga telah melaksanakan kegiatan lanjutan pada tanggal 16 Oktober 2021 untuk menjaga keberlangsungan semangat dan motivasi santri dalam menghasilkan produk inovatif bernilai ekonomis dari bahan limbah kayu. Tim pengabdi berusaha untuk memberikan pendampingan teknis kepada santri untuk terus berkreasi dalam menghasilkan produk. Tim pengabdi bersama pengasuh pondok pesantren juga memberikan penguatan kepada santri untuk mampu memasarkan produk yang telah dihasilkan. Pengalaman yang dimiliki dibagi kepada santri yang sangat antusias mengikuti kegiatan untuk tetap menjaga kualitas produk yang telah dihasilkan.

\section{Saran}

Kegiatan pengabdian kepada masyarakat ini telah berhasil dilaksanakan karena mitra pengabdian yang sangat kooperatif dan juga adanya kegiatan yang sama dari Direktorat Jenderal Industri Kecil, Menengah dan Aneka Kementerian Perindustrian. Dengan demikian, santri mendapatkan pendampingan penuh dan juga 
dukungan alat dari pemerintah. Hal ini perlu pendampingan lanjutan dari tim pengabdian agar manfaat dari alat yang diterima dapat terus dirasakan. Oleh karena itu, tim pengabdian seharusnya dapat melaksanakan kegiatan berikutnya untuk membantu santri dalam berkreasi dan juga membantu pemasaran produk yang telah dihasilkan. Pendampingan berikutnya dapat berupa pengembangan inkubasi bisnis sehingga bisa menjadi unit usaha yang produktif di pondok pesantren $\mathrm{Al}$ Asror. Pondok juga telah memiliki keunggulan lain seperti santri yang mempunyai keahlian olah kulit menjadi produk ekonomis dan keahlian lainnya. Unit bisnis pondok akan mampu memberikan kontribusi bagi pengembangan kewirausahaan santri dan juga operasional pondok pesantren jika dikelola dengan baik.

\section{DAFTAR PUSTAKA}

Badriyah, S. (2013). Pemanfaatan Bola Tenis dan Limbah Kayu sebagai Inovasi Pengrajin Furnitur di Ds. Temuwangi, Kec. Pedan Kab. Klaten.

Fachrurrozie, Wahyudin, A., Nurkhin, A., \& Mukhibad, H. (2021). Peningkatan Literasi Financial Technology bagi Santri Zaman Now dan Pengasuh Pondok Pesantren dalam Menghadapi Era
Revoluasi Industri Melalui

Penanaman Nilai dalam Kelas Inspirasi. Jurnal Pengabdian AlIkhlas, 6(3), 326-336. https://doi.org/http://dx.doi.org/10. 31602/jpaiuniska.v6i3.4503

Kardoyo, Muhsin, Fachrurrozie, \& Nurkhin, A. (2018). IbM bagi Santri di Kecamatan Gunungpati

Kota Semarang untuk

Meningkatkan Minat Berwirausaha. Jurnal Pengabdian Al-Ikhlas, 4(1), 53-65.

Mutmainnah, I. R. (2017). Pemanfaatan

Limbah Gergaji Kayu Jati

(Tectona grandits L.f) sebagai

Energi Alternatif dengan Metode

Pirolisis. UIN Alauddin Makassar.

PN Arya, N., Azhar, H., Reza, A., Pratama, M. R., \& Nugraha, M. I. (2020). Mengolah Material Limbah menjadi Smart Wall Light.

Prosiding SNADES 2020 Optimisme Desain Untuk Pembangunan Negeri, 23-29.

Sundari, S. (2017). Potensi Pemanfaatan Pelet Limbah Kayu Gergajian sebagai Sumber Energi Listrik Alternatif untuk Wilayah Jepara. Universitas Islam Nahdlatul Ulama Jepara.

Suratno, B. (2006). Kecamatan Gunungpati Kota Semarang Skripsi. Universitas Negeri Semarang.

Utomo, T. P., Suyasa, I. N., \& Haryanto, E. S. (2018). Pengembangan Desain Produk Kerajinan Berbahan Limbah Kayu Di Klaten. Abdi Seni, 9(1), 37-42. https://jurnal.isiska.ac.id/index.php/abdiseni/article /view/2454 